\title{
Seedling dynamics of Festuca spp. in a grassland of Patagonia, Argentina, as affected by competition, microsites, and grazing
}

\author{
GUILLERMO E. DEFOSSÉ, RONALD ROBBERECHT, AND MÓNICA B. BERTILLER
}

Abstract

The effects of competition, grazing, and microsites on seedling dynamics of Festuca spp. were investigated in a semiarid steppe of Patagonia, Argentina. In an exclosure and an adjacent grazed area, the level of root competition for seedlings was controlled through root exclusion tubes $(0.1 \mathrm{~m}$ diameter, $0.4 \mathrm{~m}$ long) installed adjacent to 7 similarly-sized Festuca pallescens plants and in the interspace between $F$. pallescens plants. Seedling dynamics at the phenological stages of a) recently emerged and up to 4 leaves and b) 5 leaves and up to 1 tiller were followed inside the tube area (no competition) and in paired circles (competition) for approximately 3 growing seasons. Peak density of Festuca spp. seedlings occurred in fall and early spring, when water content in the first 0 to $5 \mathrm{~cm}$ of the soil was above $8 \%$. Seedling densities of Festuca spp. at the 2 phenological stages were significantly reduced by grazing. At the phenological stage of 1 to 4 leaves, seedlings were not affected by root competition, although their densities were significantly higher for seedlings adjacent to $F$. pallescens plants than in the interspace between plants. This was due to higher soil water content in these areas throughout the season in the 0 to $5 \mathrm{~cm}$ of the soil. Seedling densities at the phenological stage of 5 leaves and up to 1 tiller were significantly higher when there was no competition from neighboring grass plants as compared to seedlings exposed to competition. In regard to microsite differences, seedling density was significantly greater in the interspaces than adjacent to mature plants. These results suggest that although higher seedling densities can be obtained by excluding the area from grazing, intraspecific competition for soil water during the summer drought period can act as a barrier for further Festuca spp. seedling establishment.

Key Words: Festuca pallescens, grassland steppe, soil water, Argentina.

In arid and semiarid ecosystcms, water is important not only in controlling plant productivity (Noy-Meir 1973, Lauenroth 1979, Defossé et al. 1990, Lauenroth and Sala 1992), but also in determining the pulse of seed germination (Mack and Pyke 1984). In these ecosystems, the successful establishment of a seedling and

\footnotetext{
The authors wish to thank Mr. Nicolás Ayling and his family, for providing the experimental site for this study.

This study was funded by a grant from the Consejo Nacional de Investigaciones Científicas y Técnicas (CONICET) de la República Argentina (PID 3058100/88). Contribution no. 799 of the Forest, Wildlife, and Range Experiment Station, University of Idaho.

Manuscript accepted 23 Mar. 1996.
}

Resúmen

Los efectos de la competencia, pastoreo y micrositios en la dinámica del establecimiento de plantúlas de Festuca spp. en una estepa semiarida de la Patagonia en Argentina. Utilizando una área excluida del pastoreo, se controló el nivel de competencia radical de las plantúlas utilizando tubos de $40 \mathrm{~cm}$. de largo y 10 cm. de diámetro, instalados junto a 7 plantas de similar tamaño de Festuca pallescens. Se observó la dinámica de las plantúlas en los estados fenologicos de: a) Recien emergidas y hasta con 4 hojas y b) De 5 hojas hasta un tallo floral, durante 3 épocas de crecimiento. La densidad máxima de plantúlas ocurrió en el otoño y al inicio de la primavera, cuando el contenido de humedad en los primeros $5 \mathrm{~cm}$. del perfil de suelo, estaba arriba de un $8 \%$. La densidad de plantúlas fue reducida significativamente por el pastoreo. En el estado de 4 hojas, las plantulas no se vieron afectadas por la competencia radicular. Las densidades de plantúlas en el estado de 5 hojas-un tallo, fueron significativamente mayores cuando no habia competencia de plantas adyacventes. En cuando a micrositios, se detectaron un mayor numero de plantúlas en los interespacios de planta y planta, que en las áreas adyacentes a plantas maduras. Estos resultados suguieren, que aunque es posible lograr altas densidades de plantúlas excluyendo el área del pastoreo, la competencia por aqua durante el verano (sequia), puede actuar como una barrera para el establecimiento de plantúlas de Festuca spp.

survival to an adult plant is determined by a series of factors, of which the availability of soil water during critical periods is one of the most important (Reichenberger and Pyke 1990). In waterlimited environments, competition for soil water between grass seedlings and established vegetation can be particularly significant (Robberecht et al. 1983). The grass steppe rangelands of western Patagonia, Argentina, are characterized by their low vegetation cover, high winds, and erratic precipitation. These rangelands, which have been subjected to continuous grazing by sheep since the beginning of the century, exhibit several typical signs of deterioration. The increased size of bare soil patches, the decreased vegetation cover, and the lack of re-establishment of native perennial plants are among the most important indicators of rangeland deterioration in western Patagonia (Soriano 1983, Ares et al. 1990).

The Sub-Andean District of the Patagonian Phytogeographic Province (Soriano 1956, Cabrera 1976) is one of the most important grazing areas of Palagonia in regard to productivity and for- 
age value (Defossé et al. 1990). In this district, the most important forage grass is $F$. pallescens (St. Yves) Parodi, a perennial cool season grass that reproduces strictly from seed (Soriano 1960 , Bertiller 1992). In many areas of this floristic district, overgrazing has reduced the cover of $F$. pallescens and species diversity, and increased bare soil patches colonized by annuals and perennials of low forage value instead of by $F$. pallescens seedlings (Ares et al. 1990). Although protection from grazing and wind has been shown to increase seedling emergence and survival of $F$. pallescens as compared to grazed and wind exposed areas, only a few individuals become established as plants in these patches. The lack of $F$. pallescens seedling establishment in these bare soil patches (or microsites in the interspace between tussocks), where other annuals and perennials succeed, suggests that differences in root phenology and water demand during critical periods might favor establishment of invaders at the expense of $F$. pallescens seedlings.

Root phenology has been shown to be an important factor in the degree of competition among seedlings of different species (Harris 1967, 1977, Harris and Wilson 1970). Among individuals of the same species, competition may be more intense, because of similarities in their growth form, seasonal timing of growth, and resource requirements (Yeaton and Cody 1976, Turkington et al. 1979). The effect of competition for soil water and its effects on seedling establishment of $F$. pallescens in the grassland steppe in Patagonia is not well understood. This study addresses one of the possible causes that prevents re-establishment of $F$. pallescens in one of the most important grassland areas of Argentine Patagonia. The objectives of this study were, therefore, to determine: (1) the effects of competition and microsites on seedling densities of Festuca spp. at the phenological stages of a) recently emerged and up to 4 leaves, and b) 5 leaves and up to 1 tiller in grazed and ungrazed areas of a Festuca grassland, (2) the dynamics of soil water in the 0 to 5 and 5 to $20 \mathrm{~cm}$ soil depth as affected by microsites and grazing, and (3) how the dynamics of soil water in different soil profiles affect seedling densities at these 2 phenological stages.

\section{Materials and Methods}

\section{Study Site}

This study was conducted in the southwestern part of the Chubut province of Argentina at the Media Luna Ranch $\left(45^{\circ} 36^{\circ}\right.$ $\mathrm{S}, 71^{\circ} 25^{\circ} \mathrm{W}, 700 \mathrm{~m}$ above mean sea level), in an area representative of the Sub-Andean Floristic District of the Patagonian Phytogeographic Province (Soriano 1956, Cabrera 1976). The site is a grass steppe dominated by $F$. pallescens, which comprised about $50 \%$ of the vegetation cover (Defossé et al. 1990, Bertiller 1992). Soils are uniformly coarse textured and well drained. They accumulate organic matter in the surface and down to $0.3 \mathrm{~m}$. A detailed description of the soils of this area has been given in Beeskow et al. (1987). The climate of this area is cold and wet in winter and warm and dry in summer. The growing season extends from September to April and seed dispersal occurs from mid- to late-summer (Bertiller et al. 1991). Average precipitation is $374 \mathrm{~mm}$ per year, $67 \%$ of which falls in winter and early spring in the form of either rain or snow. Mean annual temperature is $4.5^{\circ} \mathrm{C}$, with mean minimum in July $\left(-3.7^{\circ} \mathrm{C}\right)$ and mean maximum in January $\left(11.7^{\circ} \mathrm{C}\right)$. Freezing temperatures can occur at any time during the year, and strong westerly winds blow with high intensity all year around, and especially during spring and summer. The study site was located in an allotment of 700 ha in an area representative of this grassland. An exclosure was built in 1983 to carry out different long-term ecological studies. The grazed area outside the exclosure has becn grazed from May to December at a stocking rate of about 1.5 sheep per ha for at least the past 25 years.

\section{Competition, Microsites, and Grazing Experiment}

In the exclosure and in the adjacent grazed area, 7 similarlysized $F$. pallescens plants were selected on the basis of basal area and height measurements. Two root exclusion tubes of $0.1 \mathrm{~m}$ of diameter and $0.4 \mathrm{~m}$ long, similar to those described in Cook and Ratcliff (1984), were inserted in the soil on the leeward side of each chosen plant in the winter season prior to the start of the experiment. The length of the tubes was based on the root biomass distribution of $F$. pallescens in the soil profile. While roots of this species may reach depths of up to $1 \mathrm{~m}$ into the soil profile, $95 \%$ of the roots are concentrated in the upper 0 to $40 \mathrm{~cm}$, with the highest concentration $(80 \%)$ in the 5 to $20 \mathrm{~cm}$ soil depth (Merino 1983). One tube was placed at the outer edge of a $F$. pallescens plant (adjacent microsite). The second tube was placed $0.4 \mathrm{~m}$ from the center of the plant, in the interspace between $2 F$. pallescens plants (interspace microsite). A ring of $0.1 \mathrm{~m}$ diameter, paired to each tube, was used as a control. Seedlings in these rings would be exposed to competition. At the beginning of the study, all aerial vegetation inside the tubes and in the control paired rings was cleared with minimal disturbance of the soil seed bank.

In the early spring following the installation of the root exclusion tubes, 15 seeds of $F$. pallescens were sown both inside the tubes and in the paired rings, and covered with a thin layer of soil of approximately $1 \mathrm{~mm}$ thick. From a previous study in that area, we found that after seed dispersal, seeds of $F$. pallescens were homogeneously distributed in the soil, and that there was little or no seed transport during fall and winter (Bertiller and Coronato 1994). These characteristics of seed dispersal and distribution were important and allowed us to begin the experiment with statistically similar quantities of seeds in both leeward and central microsites in regard to both the sown seeds and seeds stored in the seed bank.

The dynamics of seedlings at 2 phenological stages were followed inside the tubes and in the paired circles for about 3 growing seasons. Because $F$. pallescens grows in association with $F$. pyrogea in the study area, and it is difficult to differentiate these species at the seedling stage, they were censused together as Festuca spp. However, the contribution of $F$. pyrogea to the aboveground biomass of this grassland is negligible as compared to F. pallescens (Defossé et al. 1990). Seedlings of Festuca spp. wcre classified then in 2 groups: (1) recently emerged and up to 4 leaves, and (2) 5 leaves and up to 1 tiller. This classification was based on a previous study in the area (Defossé and Bertiller, unpublished), in which we found that after the phenological stage of 4 leaves, seedlings of $F$. pallescens start to rapidly elongate their root system into deeper soil horizons, and may likely start to compete with adult plants for available soil water. At every sampling date, water content in the 0 to 5 , and 5 to $20 \mathrm{~cm}$ soil depth was determined gravimetrically from 12 replicates taken in adjacent and interspace microsites in both the exclosure and the grazed area. 
To determine the significance of the effects of competition of established vegetation, grazing, and microsite location on (1) densities of Festuca spp. seedlings having up to 4 leaves, and (2) densities of seedlings of Festuca spp. having from 5 leaves and up to 1 tiller, analyses of variance (SPSS for Windows, Norusis 1993) based on the square-root-transformed seedling density data werc uscd. Analysis of variance was also used to determine significant differences in soil water content in the 0 to 5 , and 5 to 20 cm soil depth as affected by sampling dates, microsites, and grazing. Unless stated otherwise, the level of significance used throughout this study was determined at the probability level of $p$ $<0.01$.

\section{Results}

\section{Influence of Soil Water}

As in many other arid and semiarid ecosystems, the availability of water in the first 0 to $5 \mathrm{~cm}$ of the soil was the determinant factor in the success of seedling emergence in the Festuca steppe. The dynamics of soil water in the first 0 to $5 \mathrm{~cm}$ of the soil showed high water availability during late fall and winter, with a steady decline from spring to summer. Water content in the 0 to $5-\mathrm{cm}$ soil depth was not significantly different in the exclosure from the grazed area (Table 1 and Fig. 1, top), but it was significantly higher in adjacent microsites as compared to interspace microsites during the different sampling dates. These differences were more noticeable during late fall, winter, and early spring (Table 1 and Fig. 1, top). In the 5 to $20 \mathrm{~cm}$ soil depth, soil water was less affected by the seasonal variation, and showed significantly higher soil water availability during the summer drought as compared to the 0 to $5 \mathrm{~cm}$ of the soil (Fig. 1, bottom). Soil water content was not significantly different in the 5 to $20 \mathrm{~cm}$ of the soil in either the exclosure as compared to grazing treatment or in adjacent as compared to interspace microsites (Table 1 and Fig. 1 , bottom).

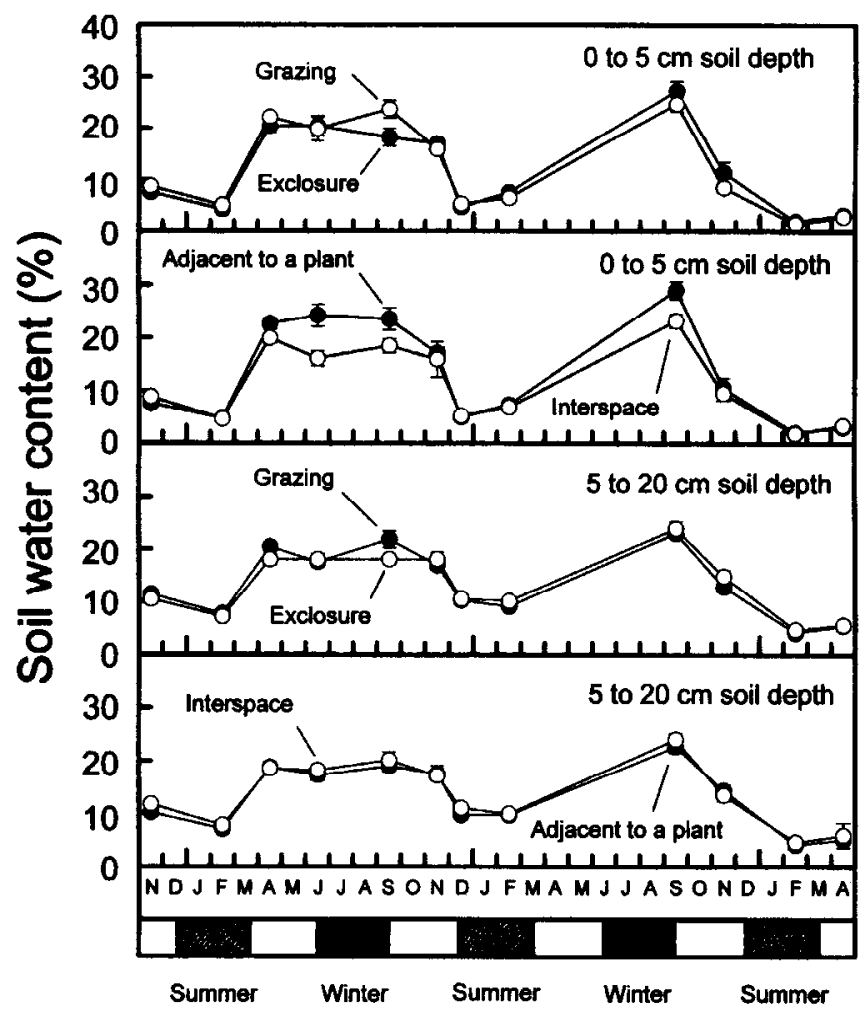

\section{Growing season}

Fig. 1. Dynamics of water in the 0 to 5 and 5 to $20 \mathrm{~cm}$ of the soil profile during 3 successive growing seasons in a steppe of Patagonia, Argentina, as affected hy grazing and microsites. Each point represents the mean \pm 1 standard error of the mean.

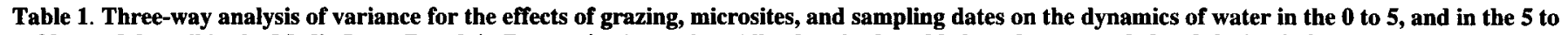
$20 \mathrm{~cm}$ of the soil in the Media Luna Ranch in Patagonia, Argentina. All values in the table have been rounded to 2 decimal places.

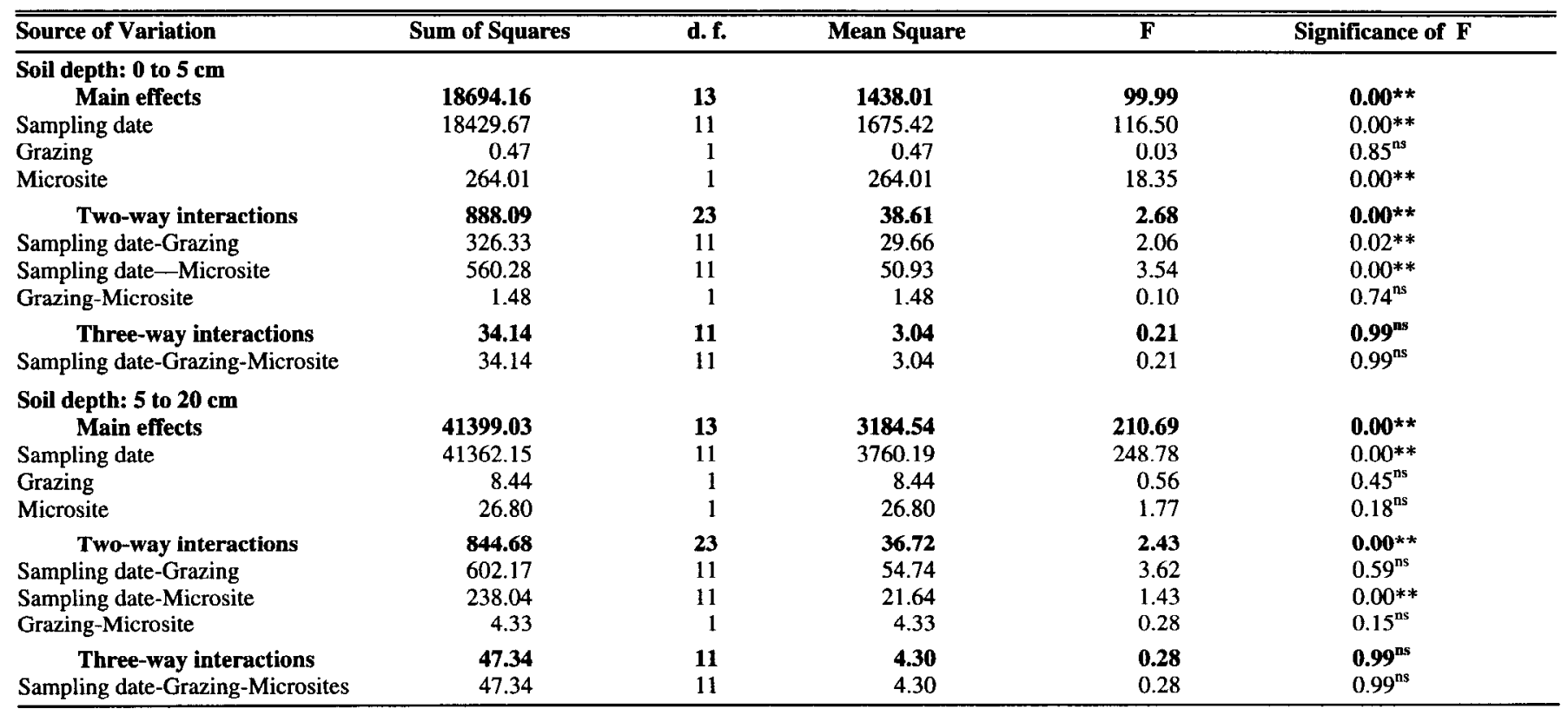

Significance: ${ }^{* *} \mathrm{p}<0.01 ;{ }^{*} \mathrm{p}<0.05 ;$ n.s. not significantly different. 


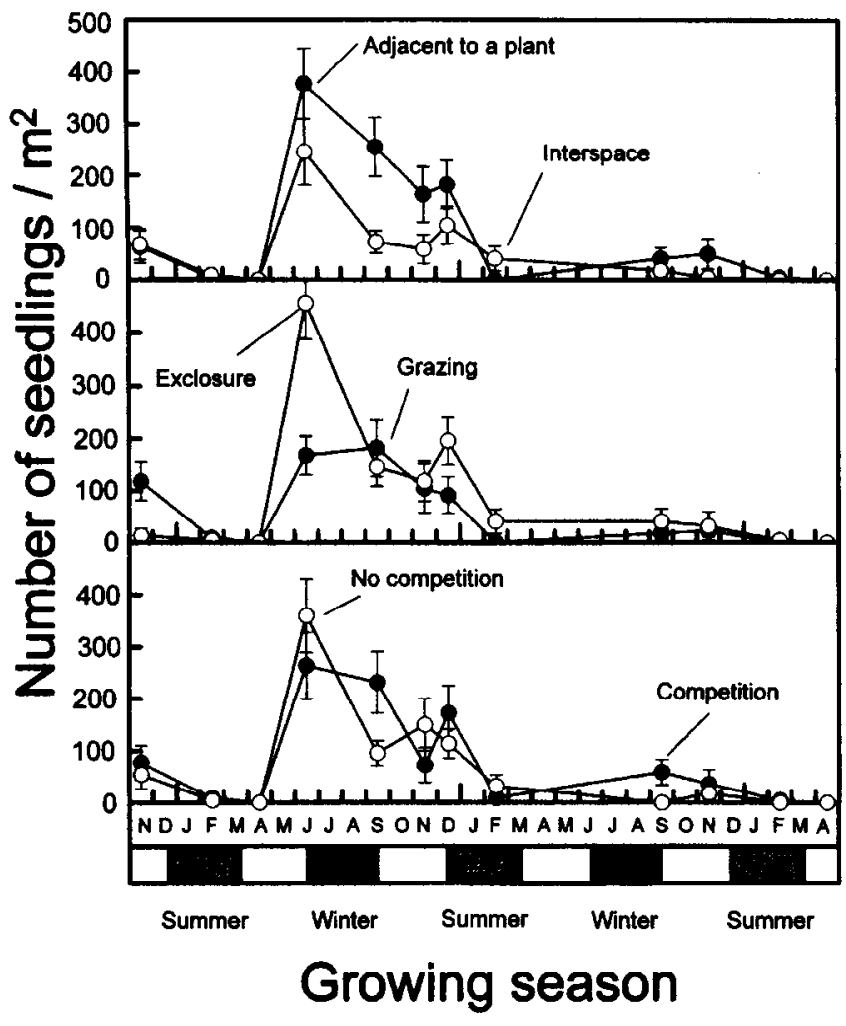

Fig. 2. Dynamics of seedlings recently emerged and up to 4 leaves as affected by microsites (top), grazing (center), and competition (bottom) during 3 successive growing seasons in a steppe of Patagonia, Argentina. Each point represents the mean \pm 1 standard error of the mean.

High soil water availability coincided with the highest densities of seedlings of Festuca spp. up to 4 leaves for the different treatments in spring and late fall over the 3 growing seasons considered (Fig. 2). Seeds were sown in September (spring) when water started to steadily diminish in the first 0 to $5 \mathrm{~cm}$ of the soil. By
November, only a portion of these seeds had emerged. Peak densities for this category occurred by the following fall, when the first 0 to $5 \mathrm{~cm}$ of the soil were replenished with water. After that peak, high densities of seedlings with up to 4 leaves occurred when soil water content was above $8 \%$ in the 0 to $5 \mathrm{~cm}$ of the soil. Densities of seedlings with 5 leaves and up to 1 tiller, by contrast, did not show any particular paltern, and after the second sampling date, they ranged in the different treatments from about 20 to 60 seedlings per $\mathrm{m}^{2}$ for the entire study period (Fig. 3).

\section{Effects of Microsites}

Similar densities of seedlings up to 4 leaves were observed in adjacent and interspace microsites during the first 3 sampling dates. For the remainder of the study period, except for the sampling done in February of the second growing season, significantly greater seedling densities were found in the microsites adjacent to adult $F$. pallescens plants as compared to microsites in the interspace between plants (Table 2 and Fig. 2, top). Except for the sampling done in November and February of the second growing season, seedlings having 5 leaves and up to 1 tiller had significantly greater density in interspace microsites as compared to adjacent microsites (Table 3 and Fig. 3, top).

\section{Effects of Grazing}

Seedling densities of all categories were similarly affected by the grazing treatment. Although the grazed area initially showed significantly higher densities of seedlings up to 4 leaves, this effect was short lived. For the majority of the study period, significantly higher densities of seedlings up to 4 leaves were found in the exclosure as compared to the grazing area (Table 2 and Fig. 2 , center). For seedlings with 5 leaves and up to 1 tiller, grazed areas showed significantly higher densities for the second and third sampling dates after sown. However, this coincided with the normal rest period in the area. When grazing resumed in this area the next season, significantly higher seedling densities were found in the exclosure as compared to the grazed area for the rest of the study period (Table 3 and Fig. 3, center).

Table 2. Four-way analysis of variance for the effects of competition, grazing, microsites, and sampling dates on emergence and survival of seedlings up to 4 leaves of Festuca spp. in a grassland of Patagonia, Argentina. All values in the table have been rounded to 2 decimal places.

\begin{tabular}{|c|c|c|c|c|c|}
\hline Source of Variation & Sum of Squares & d. f. & Mean Square & $\mathbf{F}$ & Significance of $F$ \\
\hline Main effects & 98.33 & 14 & 7.02 & 20.06 & $0.00^{* *}$ \\
\hline Sampling date & 91.29 & 11 & 8.30 & 23.70 & $0.00^{* *}$ \\
\hline Grazing & 2.13 & 1 & 2.07 & 6.21 & $0.01 * *$ \\
\hline Competition & 0.25 & 1 & 0.25 & 0.73 & $0.39^{\mathrm{ns}}$ \\
\hline Two-way interactions & 40.15 & 36 & 1.11 & 3.20 & $0.00 * *$ \\
\hline Sampling date-Grazing & 19.77 & 11 & 1.79 & 5.14 & $0.00 * *$ \\
\hline Sampling date-Microsite & 10.38 & 11 & 0.94 & 2.69 & $0.00 * *$ \\
\hline Grazing-Competition & 0.09 & 1 & 0.09 & 0.26 & $0.60^{\mathrm{ns}}$ \\
\hline Microsite-Competition & 0.17 & 1 & 0.17 & 0.49 & $0.48^{\mathrm{ns}}$ \\
\hline Three-way interactions & 28.88 & 34 & 0.67 & 1.92 & $0.00^{* *}$ \\
\hline Sampling date-Grazing-Microsite & 6.76 & 11 & 0.61 & 1.75 & $0.04 *$ \\
\hline Sampling date-Grazing-Competition & 8.99 & 11 & 0.81 & 2.32 & $0.00^{* *}$ \\
\hline Sampling date-Microsite-Competition & 7.07 & 11 & 0.64 & 1.83 & $0.04 *$ \\
\hline
\end{tabular}

Significance: ${ }^{* *} p<0.01 ;{ }^{*} p<0.05$; n.s. not significantly different. 


\section{Effects of Competition}

Competition affected seedling densitics at the 2 phenological stages differently. Also, of the factors examined in this study, belowground competition was the single most important factor for seedling survival of older seedlings (see Fig. 3). Densities of young seedlings, i.e., those with up to 4 leaves, were not significantly different for plants not exposed to competition (inside root exclusion tubes) or exposed to competition (outside exclusion tubes) (Table 2 and Fig. 2, bottom). In contrast, older seedlings, i.e., those with 5 leaves and up to 1 tiller, were significantly affected by belowground competition. Densities of these older seedlings was significantly lower in response to competition as compared to seedlings that were not exposed to competition (Table 3 and Fig. 3, bottom).

\section{Discussion}

In water-limited environments, the availability of water near the soil surface appears to be a key factor for seedling emergence and survival (Wilson and Briske 1978, Mack and Pyke 1984). As found in the Patagonian grassland steppe studied, seedling emergence was most affected by soil water in the top $5 \mathrm{~cm}$ of the soil. In addition to the importance of soil water near the surface, the proximity of a seedling to an adult plant, e.g., on adjacent microsites, appeared to be an important factor. These adjacent microsites had higher soil water content near the surface than the microsites in the interspace between tussocks, and thus provided a more suitable microenvironment for seedlings in the younger age group. However, as seedlings developed a more extensive root system and used water deeper in the soil profile, their densities decreased on adjacent microsites relative to interspace microsites. Higher survival of older seedlings in the interspace microsite was also observed by Soriano and Sala (1986). Although water content was similar between adjacent and interspace microsites at the greater soil depths, the higher densities of older seedlings found in interspace microsites was due to lower competition for soil water in those microsites; interspace

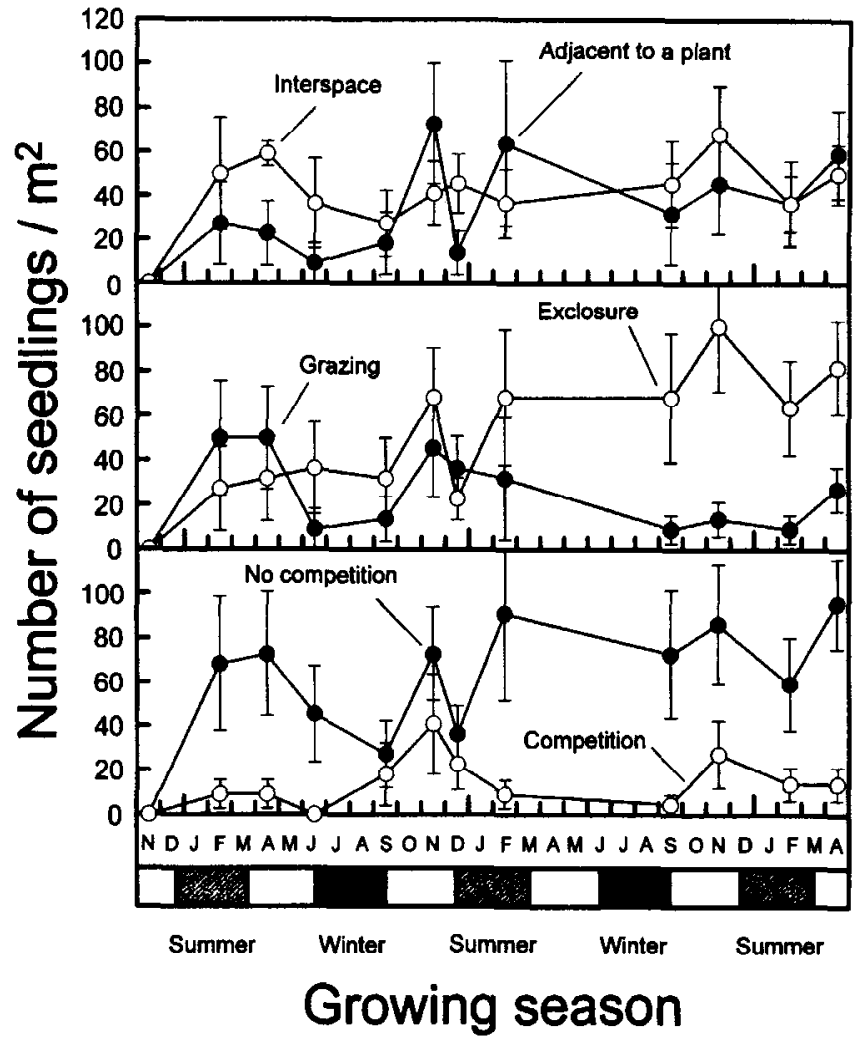

Fig. 3. Dynamics of seedlings with 5 leaves and up to 1 tiller during 3 successive growing seasons as affected by microsites (top), grazing (center), and competition (bottom) in a grassland of Patagonia, Argentina. Each point represents the mean \pm 1 standard error of the mean.

microsites had lower root concentrations than microsites adjacent to adult plants (Soriano et al. 1987).

Competition for soil water was also a significant factor in the grassland steppe, especially for older seedlings. Densities of younger seedlings, i.e., those with up to 4 leaves, were not affect-

Table 3. Four-way analysis of variance for the effects of competition, grazing, microsites, and sampling dates on survival of seedlings of $F$ estuca spp. having 5 leaves and up to one tiller in a grassland of Patagonia, Argentina. All values in the table have been rounded to 2 decimal places.

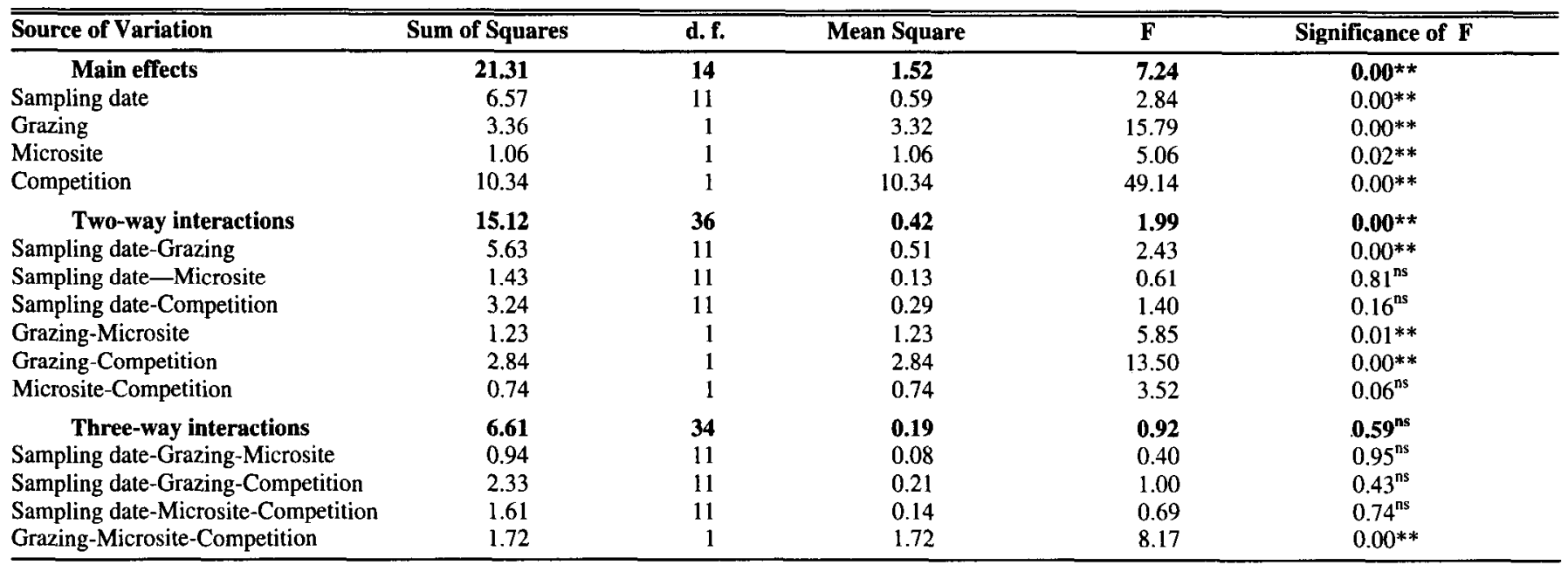

Significance: ${ }^{* *} \mathrm{p}<0.01 ;{ }^{*} \mathrm{p}<0.05 ;$ n.s. not significantly different. 
ed by belowground competition. These younger seedlings, which had shallow root systems, relied mostly on the availability of water in the 0 to $5 \mathrm{~cm}$ soil layer, and were unaffected by root competition with adult plants. Older seedlings, i.e., those with 5 leaves and up to 1 tiller, in contrast, were severely affected by root competition from adult $F$. pallescens plants. In a study carried out in a different area of the same grassland as the present study, Abadie (1967) found that after several years of grazing exclusion, $F$. pallescens bunchgrasses increase in size, yet little or no seedling establishment of $F$. pallescens occurred. This also suggests that competition between older seedlings and adult $F$. pallescens might be significant. Intraspecific competition may be more detrimental for survival of older seedlings than interspecific competition, since seedlings and adult plants share similar root and shoot phenology and similar water demands (Yeaton and Cody 1976, Robberecht et al. 1983). Differences in root phenology among species have been shown to be an important factor in seedling establishment of different species in semiarid ecosystems (Harris 1967, 1977, Harris and Wilson 1970, Reichenberger and Pyke 1990). In the Patagonian grassland steppe, the failure of Festuca spp. seedling establishment may be due, in part, to competition for soil water during critical periods with adult Festuca plants. The increased prevalence of adventive and other native annuals and perennials in the Patagonian grassland steppe may be related in part to differences in root phenology and water demands between these adventive species and seedlings of Festuca spp.

Grazing also appeared to be a significant factor in this grassland steppe, as evidenced by the consistently higher seedling densities of both categories found in areas protected from grazing. Since soil water availability for the entire soil profile, the number of seeds in the germinable seed bank (Bertiller 1992, Bertiller and Coronato 1994), and the number of seeds sown were similar in the exclosure and the grazed area at the beginning of this study, the significant reductions found in seedling densities at the 2 phenological stages studied between protected and grazed areas were due to the effects of grazing and trampling. The detrimental effects of grazing were more severe on microsites in the interspaces than on microsites adjacent to adult plants, and indicated that sheep tended to step between tussocks instead of on or adjacent to tussocks. This is consistent with Balph and Malecheck (1985), who found higher trampling incidence on tussock interspaces than on tussocks in a semiarid Agropyron grassland. Grazing has been suggested to either promote (Savory and Parsons 1980, Savory 1983, Gibson et al. 1987, Oesterheld and Sala 1990) or to reduce (Mack and Pyke 1984, Salihi and Norton 1987) seedling establishment. These apparent contradictory findings may be due to variations in the grazing treatment, and thus the specific effects of grazing appears to be highly related to the season of grazing, the kind of grassland grazed, and the stocking rate used. In the Patagonian grassland steppe, the season of grazing and the stocking rate used has been shown to be detrimental for Festuca spp. seedling establishment.

\section{Literature Cited}

Abadie, C.A. 1967. La regeneración de Festucapallescens (St. Yves) Parodi, en los pastizales del oeste del Chubut. Rev. Inst. Inv. Agr. 239:58-64.
Ares, J.O., A.M. Beeskow, M.B. Bertiller, C.M. Rostagno, M.P. Irisarri, J. Anchorena, G.E. Defossé, and C.A. Merino. 1990. Structural and dynamic characteristics of overgrazed grasslands of northern Patagonia, p. 149-175. In: A. Breymeyer (ed.), Managed Grasslands: regional studies. Elsevier, Amsterdam.

Balph, D.F. and J.C. Malecheck. 1985. Cattle trampling of crested wheatgrass under short-duration grazing. J. Range Manage. 38:226-227.

Beeskow, A.M., H. del Valle, and C.M. Rostagno. 1987. Los sistemas fisiográficos de la región árida y semiárida de la provincia del Chubut, Argentina. Secretaría de Estado de Ciencia y Técnica, Delegación Regional Patagónica, San Carlos de Bariloche, Rio Negro, Argentina.

Bertiller, M.B. 1992. Seasonal variation in the seed bank of a Patagonian grassland in relation to grazing and topography. J. Veg. Sci. 3:47-54.

Bertiller, M. B. and F. R. Coronato. 1994. Seed bank patterns of Festuca pallescens in semiarid Patagonia (Argentina): a possible limit to bunch reestablishment. Biodiversity and Conservation 3:47-57.

Bertiller, M.B., M.P. Irisarri, and J.O. Ares. 1991. Phenology of Festuca pallescens in relation to topography in northwestern Patagonia. J. Veg. Sci. 1:579-584.

Cabrera, A.L. 1976. Las regiones fitogeográficas Argentinas. Enciclopedia Argentina de Agricultura, Jardinería y Horticultura, Tomo I. ACME Press, Buenos Aires, Argentina.

Cook, S.G. and D. Ratcliff. 1984. A study of root and shoot competition on the growth of green panic (Panicum maximum var. trichoglume) seedlings in an existing grassland using root exclusion tubes. J. Appl. Ecol. 21:971-982.

Defossé, G.E., M.B. Bertiller, and J.O. Ares. 1990. Aboveground phytomass dynamics in a grassland steppe of Patagonia, Argentina. J. Range Manage. 43:157-160.

Gibson, C.W.D., T.A. Watt, and V.K. Brown. 1987. The use of sheep to recreate species-rich grassland from abandoned arable land. Biolugical Conserv. 42:165-183.

Harris, G.A. 1967. Some competitive relationships between Agropyron spicatum and Bromus tectorum. Ecol. Monogr. 37:89-111.

Harris, G.A. 1977. Root phenology as a factor of competition among grass seedlings. J. Range Manage. 30:172-177.

Harris, G.A. and A.M. Wilson. 1970. Competition for moisture among seedlings of annual and perennial grasses as influenced by root elongation at low temperature. Ecol. 41:530-534.

Lauenroth, W.K. 1979. Grassland primary production: North American grasslands in perspective, p. 3-21. In: N. French (ed.) Perspectives in grassland ecology. Ecological studies 32. Springer-Verlag, New York, N.Y.

Lauenroth, W.K. and O.E. Sala. 1992. Long term forage production of North American shortgrass steppe. Ecol. Appl. 2:397-403.

Mack, R.N. and D.A. Pyke. 1984. The demography of Bromus tectorum: the role of microclimate, grazing, and disease. J. Ecol. 72:731-748.

Merino, C.A. 1983. Dinámica de la biomasa y crecimiento de raíces de dos areas de pastoreo de la Pcia. del Chubut y su correlación con algunos factores ambientales y edáficos. Informe Técnico BID-CONICET Nro. 2999/113. Centro Nacional Patagónico, Puerto Madryn, Argentina. 33 pp.

Noy-Meir, I. 1973. Desert ecosystems: environment and producers. Ann. Rev. Ecol. Syst. 4:25-41.

Norusis, M.J. 1993. SPSS for Windows: Base System's User Guide. SPSS Inc., Chicago, Ill.

Oesterheld, M. and O.E. Sala. 1990. Effects of grazing on seedling establishment: the role of seed and safe site availability. J. Veg. Sci. 1:353-358.

Reichenberger, G. and D.A. Pyke. 1990. Impact of early root competition on fitness components of four semiarid species. Oecologia $85: 159-166$

Robberecht, R., B.E. Mahall, and P.S. Nobel. 1983. Experimental removal of intraspecific competitors-effects of water relations and productivity of a desert bunchgrass, Hilaria rigida. Oecologia 60:21-24.

Salihi, D.O. and B.E. Norton. 1987. Survival of perennial grass seedlings under intensive grazing in semiarid rangelands. J. Appl Ecol. 24:145-151. 
Savory, A.G. 1983. The Savory grazing method or holistic resource management. Rangelands 5:155-159.

Savory, A.G. and S.D. Parsons. 1980. The Savory grazing method. Rangelands 2:234-237.

Soriano, A. 1956. Los distritos florísticos de la Provincia Patagónica Rev. Inv. Agr. 10:323-348.

Soriano, A. 1960. Germination of twenty dominant plants in Patagonia in relation to regeneration of vegetation, p. 154-158. In: Proc. 8th Int. Grassland Congress. London, England.

Soriano, A. 1983. Deserts and semideserts of Patagonia, p. 423-460. In: N. E. West (ed.), Temperate deserts and semideserts. Elsevier, Amsterdam.

Soriano, A. and O.E. Sala. 1986. Emergence and survival of Bromus setifolius seedlings in different microsites of a Patagonian arid steppe Isr. J. Bot. 35:91-100.
Soriano, A., R.A. Golluscio and E. Satorre. 1987. Spatial heterogeneity of the root system of grasses in the Patagonian arid steppe. Bull. Torrey Bot. Club 114:103-108.

Turkington, R., M.A. Cahn, A. Vardi and J.L. Harper. 1979. The growth, distribution and neighbour relationships of Trifolium repens in a permanent pasture. III. The establishment and growth of Trifolium repens in natural and disturbed sites. J. Ecol. 67:231-243.

Wilson, A.M. and D.D. Briske. 1978. Drought and temperature effects on the establishment of blue grama seedlings, p. 359-361. In: D.N. Hyder (ed.), Proc. 1st Int. Rangeland Congress Soc. Range Manage. Denver, Colo.

Yeaton, R.I. and M.L. Cody. 1976. Competition and spacing in plant communities: the northern Mojave Desert. J. Ecol. 64:689-696.

\section{Reminder!}

The Trailboss News will be mailed separately starting in January 1997 and not as a supplement with the Journal or Rangelands. This will enable the TBN staff to publish more current information to the SRM membership. If you have information or position announcements to be published in the Trailboss News please have it to the Denver office by the 1st of the month. Due to publication scheduling information after the first may not be published. For further information contact the Patty Rich or Marlene Richards at 303-355-7070. 